\title{
Tourism Management as an Economic Development Tool in Iran
}

\author{
Mohammad Taleghani (Corresponding author) \\ Department of Management \& Accounting, Tonekabon Branch \\ Islamic Azad University \\ Tonekabon, Mazandaran , Iran \\ Tel: +98-911-131-4029Ｅ-mail:M.taleghani454@yahoo.com
}

\author{
Azita Sherej Sharifi \\ Department of Accounting, Noshahr Branch \\ Islamic Azad University \\ Noshahr, Mazandaran , Iran \\ Tel: +98-935-616-7840Ｅ-mail: Sharifi@iauns.ac.ir \\ Seyyed Javad Mousavian \\ Department of Management, Astara Branch \\ Islamic Azad University, Astara, Iran \\ Tel: +98-911-335-4617Ｅ-mail:saba_moosaviyan@yahoo.com
}

Received: June 10, 2011

doi:10.5430/ijba.v2n4p69
Accepted: August 16, $2011 \quad$ Published: November 21, 2011

URL: http://dx.doi.org/10.5430/ ijba.v2n4p69

\begin{abstract}
Probably the greatest single deterrent to tourism development is the lack of appreciation and enthusiasm for tourism by civic and business leaders. When tourism is not understood and its benefits are unclear, planning and implementation of measures to improve the industry are often lacking. Global tourism has become the largest industry in the world, with nearly 500 million consumers of tourism services per year spending hundreds of billions of dollars. The industry provides employment to over 100 million people worldwide. In view of tourism's increasing role in economic activity, the factors affecting its performance should be analyzed. An understanding of these factors is crucial to determine the ways in which national and international financial institutions, NGOs, and other entities can play the most value-adding role. This paper provides a brief profile of key factors and trends in tourism and their economic effects at the global, national and regional levels.
\end{abstract}

Keywords: Tourism, Economic Development, Supply and Demand, GDP

\section{Introduction}

The most important economic feature of activities related to the tourism sector is that they contribute to three highpriority goals of developing countries: the generation of income, employment, and foreign-exchange earnings. In this respect, the tourism sector can play an important role as a driving force of economic development. The impact this industry can have in different stages of economic development depends on the specific characteristics of each country. "Given the complexity of tourism consumption, its economic impact is felt widely in other production sectors, contributing in each case towards achieving the aims of accelerated development" (Davidson, 2004) .

A major difficulty in defining the boundaries of the tourism sector is to ascertain what investment costs should be ascribed to the development of tourism. Although heretofore not treated by international agencies as a "sector" in national accounting terms, tourism entails a collection of goods and services that are provided specifically for visitors and would not have been provided otherwise. 
Because of its interdependence with other sectors of the economy, it is difficult to analyze and plan for tourism. The lack of reliable statistical data hampers identification of the mechanisms by which tourism generates growth, as well as its potential for development. Yet, in those instances where analysis has been carried out and research has preceded planning, tourism's priority in competing for scarce investment funds has been established. In these cases, long term programs for tourism development have been designed.

Nature and heritage tourism development has investment needs that differ, in certain respects, from traditional hotel development. There may be a greater need to improve access to the attraction site or facility, and for a mode of development that does not interfere with a sensitive habitat or historic area (Eadington\& Redman, 2001) .

\section{Elements of Supply and Demand}

There primary factors influence the level of nature and heritage tourism demand: overall tourism growth, the growth in specialty travel, and increasing awareness of and concern for the environment. Each of these factors is in turn influenced by a number of elements. Overall tourism, for instance, is expected to continue to grow more rapidly than world economic output as a result of factors such as population growth, rising incomes and employment, shorter work weeks in many parts of the world, and the increasing integration of the world's economies and societies. The rapid growth of specialty travel is fueled by some of the same factors, but there are a number of additional explanations: the boom in outdoor recreation and the new interest in health and fitness, for example. Environmentalism is another of the elements that have changed people's attitudes about how they should spend their vacations.

The importance of Location. People with incomes high enough for foreign travel are concentrated in a few countries. Most developing countries are far from key points of origin. In this regard, countries like Mexico and some Caribbean islands that are close to the United States and Canada benefit from a comparative advantage. These tourist destinations reaped early success in promoting their attractions (Murphy, 2003).

Income Elasticity. In several countries, travel receipts have been the fastest-growing export item. The tourism sector represents over two thirds of the value of total exports of goods and services from the Bahamas, three fifths of those from Barbados, and over one third from the Dominican Republic and Jamaica. As national incomes increase, expenditure on travel increases even faster (Note 1). As a result of this trend, international receipts from foreign travel have been increasing by nearly 11 percent a year (over 8 percent in constraint prices) or more than twice the rates of national incomes (Hogan\& Mcpheters, 2003).

Decreasing Travel Costs. There is evidence that tourism demand as also price-elastic, particularly below certain price levels. The two major costs of a trip abroad are transport charges and expenditures in the destination country. For longdistance traffic, air transport is predominant, and average air transport costs have been declining. Where such transport costs constitutes a high potential of the total cost of a trip, this decline is of great significance for the potential for the long-distance travel growth.

Public and Private Sector Involvement. Tourism is mainly a private sector enterprise, but the timely provision of hotel and other visitor services, such as entertainment, food, and sport facilities, requires public-sector participation in the form of infrastructure, promotional support, and fiscal and financial incentives, so as to attract private investment to the sector.

Availability of credit. Another important factor directly related to tourism facilities is the availability of credit on suitable terms is an essential catalyst for sound tourism investment. In a number of countries, when the private financial system does not provide it, the public sector has established credit lines for tourism investment.

Tourist Destination Attributes. Tourist demand is spurred by innovation in the type of holidays offered (new commodities) and by improvements in transport, accommodations, and attractions (quality changes). The tourism sector offers a multidimensional product that, if vigorously promoted, is likely to lead to changes in the pattern of demand and general new demand for services. Yet, as in any other sector of economic activity, a minimum set of parameters needs to be in place in order to make an investment viable. In this sense, it is important to identify those attributes of a destination area that are necessary to attract tourism projects and make them viable. Such attributes relate to at least six different categories: climate, natural resource Infrastructure, amenities, culture, and socioeconomic and political factors. The table below presents these categories with their related attributes (Inskeep, 2008) .

$<$ Table 1 about here $>$

An ideal combination of these attributes should result in forms of tourism development that maximize returns to the economy, to the investors, and to the consumers of tourism services. 


\section{Tourism and GDP}

The tourism sector in the Latin American and Caribbean countries contributes significantly to GDP earnings, though this contribution is not reflected in the domestic income and product accounts of most countries. In The Bahamas, tourism accounts for about one-third of GDP, and most sectors of economic activity are directly or indirectly linked to it. In Barbados, tourism is the leading economic sector, accounting for 15 percent of the GDP in 2002. In Jamaica, the tourism contribution to GDP was 13.4 percent in 2002, while in Mexico it was only 4 percent, and in Iran it has been accounted for about 1.3 percent.

Not all tourism receipts are retained within the economy. In fact, there is an outflow of foreign exchange for some of the goods and services consumed by visitors, as well as for capital goods invested in tourism and for payments abroad. Import needs depend on the level of development and the degree of diversification of substitutes for imported products and on the qualitative level of the tourist supply in each country (WTO, 2000) .

\section{Tourist Income Multiplier and Value-Added}

The tourist income multiplier (time) is a coefficient that expresses the amount of income generated by a unit of tourism expenditure (Note 2). In Jamaica, a stopover visitor spending one dollar creates a ripple effect of US \$ 1.60 within the local economy, while a dollar spent by a cruise-ship visitor generates US \$ 1.20. In the Dominican Republic, the time has been estimated at US\$1.70.

The value-added concept is particularly important when considering the impact of tourism in the Caribbean region. Value is added when a product is developed, processed, refined, or remarked in a manner that allows it to be sold at a higher price than the prices of the raw materials, services, and agricultural sectors supplying tourist consumption are well positioned to achieve higher levels of value-added in the tourism sector.

When a country's natural resources are packaged by foreign tour operators and sold through sophisticated marketing techniques, a substantial portion of the value-added is created and captured by those tour operators and therefore not returned to the country (Murphy, 2005). To increase the value-added of tourism, host-country businesses and residents must offer travel services such as packaged tours ("land services"), offering locally owned accommodations and providing the necessary means to visit natural areas.

\section{Income Distribution Effect (IDE) and Employment}

The IDE offers one of the strongest socioeconomic arguments in favor of tourism development. It describes how income generated by the sector is distributed. The analysis can be undertaken at a spatial and at a functional level.

At the spatial level, tourists prefer to travel in regions with little industrial development. They also tend toward areas of little agricultural value. For these reasons, tourism can become a dynamic force in regional economies. Within a country, tourism demand originates in urban concentrations where the highest incomes are found. A percentage of such incomes is normally set aside for tourism in areas are geographically different from the visitors' home base, reinforcing the process of internal income redistribution. Internationally, a portion of the tourism consumption by developed countries occurs in developing countries, favoring the process of international income redistribution (Williams\&Shaw, 2009).

At the functional level, the income generated tends to favor employment, which is estimated to contribute more to the total value-added of the industry than other factors do, because so much of tourism involves personal services. It has been estimated that, worldwide, tourism directly or indirectly supports sixty-five million jobs, including hotel managers and staff, taxi drivers, tour operators, and shop attendants, among others. Secondary employment is generated in agriculture, industry, handicrafts, and services.

Tourism compares favorably with other economic activities as a generator of both employment and income, toothy directly and diffused though the economy. An OAS study on new hotel development in the Caribbean estimates that every investment of US\$ 80,000 in the tourism industry in the region generates forty-one jobs (Note 3) (Organization of American States.2005) The same investment would create only sixteen new jobs in the petroleum industry and fifteen in metallurgy. According to the CTO, the 77,319 hotel rooms in fifteen Caribbean countries equaled 88,697 jobs, or almost 1.15 per room (Note 4) (Caribbean Tourism Organization, 2005)

Hotels account for about 75 percent of tourism employment (distribution, transport, finance and insurance, and entertainment make up the other 25 percent). Every room in a three or four star hotel in Venezuela generates one job, according to the IDB; for five-star hotels, each room creates 1.3 jobs. According to the OAS study, one job generated by a hotel generates one more job elsewhere in the tourism trade and two in the rest of the economy; thus one job generates an estimated three others. The tourism sector, particularly hotels, can play important role in attracting foreign investment and providing training for nationals. Many tourism ventures include foreign equity participation and technical 
knowledge about the construction and operation of hotels. The former represents a mobilization of international financial resources, which can be regarded as a desirable substitute for foreign borrowing. Outside management can be used to train large numbers of nationals who would not otherwise have access to training. Furthermore, business provides a stimulus for the development of other ancillary businesses catering to tourists (WTO \& IHRA, 2009).

\section{Tourism and Balance of Payments}

Tourism can make an important contribution to a country's balance of payments. Tourism offers developing countries the possibility of diversifying their export earnings, particularly given that (i) traditional exports are subject to price fluctuations and (ii) there is a trend toward reducing the administrative, monetary, and border formalities that affect international tourism mobility.

With only a few exceptions, the terms of trade for developing countries, i.e., the ration between the prices that a country receives for its exports and the prices it pays for its imports have traditionally been unfavorable, because of fluctuations in the prices of raw-material exports. But in the case of international tourism, if the index of average international tourist expenditure it has taken as the expression of the price of the international product, the prices received have enjoyed greater stability than the prices of raw materials- in fact, prices have tended to increase in a stable manner, because, among other reasons, of the demand for holidays, the growth of business travel, and the rigidity of destination supply in the short and medium term (Kottke, 2008). Whereas the prices of other products are affected by speculative or strategic offers, this is generally not the case with tourism. It is therefore a sector that trends to improve the terms of trade of an economy in the medium as well as the short term.

\section{Tourism the Most Important Economic Activity}

For many third world countries, tourism has become the most important economic activity, especially as the major earner of foreign exchange. This is in part the result of the declining importance of sugar, bananas, bauxite, and oil as engines of growth. But it is also a reflection of the increasing importance given to recreation and leisure as a result of rising world income levels. In addition, unlike many goods and services, tourism has no exact substitutes, meaning that the demand for holidays will grow rather than be raided for something else.

Political boundaries that split regions, metropolitan areas or other natural market areas may also be at issue. Differences in local values and laws can have a dramatic effect on the apparent relative attractiveness of two otherwise comparable areas. The tourism effects appear most often when two adjacent jurisdictions have differing policies on such controversial recreational and entertainment activities as legalized gambling or the sale and consumption of alcoholic beverages. Often, however, in these cases, customers are drawn from the local or regional market (Beckhuis, 2001). Thus, less of an "export" effect is created from spending and therefore little economic stimulus is added to the region. Nonetheless, in comparison with nearby jurisdictions which do not permit these activities, the counties or communities permitting such activities can be tremendously successful- as measured by revenues and jobs created at the local level.

The following table summarizes the economic impacts and demonstrates the multiplier effects of adding 100 tourists on job creation in a community.

$<$ Table 2 about here $>$

\section{Conclusion}

Research found that an average of 22.4 direct and indirect jobs is created in non-metropolitan counties for each \$1 million of new demand for final output from the hotel and amusements industries. The impact on metropolitan areas was slightly higher at 27.4 new jobs created. The increase in demand for hotel and amusement services affected almost all major sectors of the business community as shown in the following table. As may be expected, the greatest impact is on direct employment in the hotel and amusement industries, where 12.7 and 14.5 jobs were created in rural counties and metro areas respectively (WTO, 2006).

$<$ Table 3 about here $>$

There are other local revenues that are not easily quantified, as not all tourist expenditures are formally registered in the macro-economic statistics. Money is earned from tourism through informal employment such as street vendors, informal guides, rickshaw drivers, etc. The positive side of informal or unreported employment is that the money is returned to the local economy, and has a great multiplier effect as it is spent over and over again. The World Travel and Tourism Council estimate that tourism generates an indirect contribution equal to $100 \%$ of direct tourism expenditure. 


\section{References}

Beckhuis, J.V.(2001). Tourism in the Caribbean: Impacts on the Economic, Social and Natural Environment. AMBIO 10(6): 325-331.

Caribbean Tourism Organization, Caribbean Tourism Statistical Report, 2008.

Davidson, T.L. (2004). What are travel and tourism: Are they really an industry? In W.P. Theobold (Ed.), Global tourism (p. 22-28). Oxford: Butterworth-Heinemann.

Eadington, W.R., and Redman, M. (2001). Economics and Tourism. Annals of Tourism Research 18(1): 41-56. http://dx.doi.org/10.1016/0160-7383(91)90038-D

Hogan, T.D., and Mcpheters, L.R. (2003). The Economic Impact of Tourism on the Arizona Economy. Annals of Tourism Research 10(4): 561-564. http://dx.doi.org/10.1016/0160-7383(83)90011-7

Inskeep, E. (2008). Tourism Planning: An Emerging Specialization. Journal of the American Planning Association 54(3): 360-372. http://dx.doi.org/10.1080/01944368808976497

Kottke, M. (2008). Estimating Economic Impacts of Tourism. Annals of Tourism Research 15(1): 122-133.

Murphy, P.E. (2003). Tourism in Canada: Selected Issue and Options. Western Geographical Series. Victoria: University of Victoria.

Murphy, P.E. (2005). Tourism: A Community Approach. New York: Methuen.

Organization of American States.(2005). The Optimum Size and Nature of New Hotel Development in Caribbean, Washington, D.C.

Williams, A.M., and Shaw, G. (2009). Tourism and Economic Development. London: Belhaven Press-Printer Publishers.

World Tourism Organization (WTO).(2000). Tourism highlights 2000. Madrid: World Tourism Organization.

World Tourism Organization (WTO).(2006). Guide for local authorities on developing sustainable tourism. Madrid: World Tourism Organization.

World Tourism Organization \& International Hotel and Restaurant (WTO \& IHRA).(2009). Tourism and sustainable development: The global importance of tourism. Background paper \# 1. Geneva: United Nations Department of Economic and Social Affairs.

\section{Notes}

Note 1. A model developed by the IDB for seventeen major source countries gave a weighted average of 1.7 for the income elasticity of tourism demand.

Note 2. The calculation are based on the familiar Keynesian multiplier K=1/MPS+ MPM, where MPS is the marginal propensity to save and MPM the marginal propensity to import (or to spend on tourism abroad).

Note 3. Organization of American States. The Optimum size and Nature of New Hotel Development in the Caribbean, Washington, D.C., 2005.

Note 4. Caribbean Tourism Organization, Caribbean Tourism Statistical Report, 2008.

Table 1.Tourist destination attributes

\begin{tabular}{|c|c|c|c|c|c|}
\hline Climate & Natural & Infrastructure & Amenities & Cultural & $\begin{array}{c}\text { Socioeconomic } \\
\text { political }\end{array}$ \\
\hline Temperature & Beaches & Water/energy & Accommodations & Historic & Industrial \\
Rainfall & Lakes & Supply & Tourism & Features & Structure \\
Humidity & Rivers & Drainage & Organizations & Theaters & Government \\
Sunshine & Forests & Telecommunications & Restaurants & Concert & Structure \\
& Mountains & Roads & Shopping & Halls & Planning \\
& Flora & Railways & Sport facilities & Art galleries & System \\
& Fauna & Ports & Recreational & Museums & Language \\
& & Airports & Parks & Architecture & Religion \\
& & Waste removal & Zoos & Exhibitions & Gastronomy \\
& & & Entertainment & Festivals & Hospitality \\
\hline
\end{tabular}


Table 2. What 100 tourists a day mean to a community (jobs created)

\begin{tabular}{|c|c|c|c|c|}
\hline Industry & Transportation & Retail & Hotels and amusement & Eating and drinking places \\
\hline Construction & 0.19 & 0.41 & 0.52 & 0.19 \\
\hline Manufacturing & 0.84 & 1.91 & 2.43 & 1.87 \\
\hline Transportation & 8.21 & 0.68 & 0.87 & 0.37 \\
\hline Communication \& utilities & 0.19 & 0.55 & 0.70 & 0.28 \\
\hline Wholesale trade & 0.39 & 0.68 & 0.87 & 0.94 \\
\hline Retail trade & 0.97 & 34.24 & 2.09 & 1.12 \\
\hline Finance insurance \& real estate & 0.65 & 1.36 & 1.22 & 0.75 \\
\hline Hotel amusements & 0.13 & 0.27 & 22.08 & 0.19 \\
\hline Eating \& drinking & 0.78 & 2.05 & 1.74 & 24.84 \\
\hline Services & 2.13 & 5.73 & 6.26 & 2.72 \\
\hline Other & 0.06 & 0.00 & 0.17 & 0.09 \\
\hline Total jobs created & 14.45 & 47.87 & 38.95 & $33.37=134.75$ \\
\hline
\end{tabular}

Table 3. Jobs created from $\$ 1$ million in new demand for final output for hotels and amusements

\begin{tabular}{|c|c|c|}
\hline Industry & County & Metro area \\
\hline Construction & 0.3 & 0.4 \\
\hline Manufacturing & 1.4 & 1.9 \\
\hline Transportation, communication \& utilities & 0.9 & 1.1 \\
\hline Wholesale trade and retail trade & 1.7 & 2.4 \\
\hline Finance insurance \& real estate & 0.7 & 1.0 \\
\hline Hotel \& amusements & 12.7 & 14.5 \\
\hline Services & 4.6 & 5.9 \\
\hline Other & 0.1 & 0.2 \\
\hline Total jobs created & 22.4 & 27.4 \\
\hline
\end{tabular}

